\title{
2004年 7 月新潟豪雨と10月新潟県中越地震による斜面崩壊の判別分析 Discriminant analysis for landslides caused by the 2004 Niigata heavy rainfall in July and the Mid Niigata Prefecture Earthquake in October
}

\author{
岩橋純子 ${ }^{\text {a) }} \cdot$ 山岸宏光 ${ }^{b)} \cdot$ 神谷 泉 $^{\text {a) }} \cdot$ 佐藤 浩 $^{\text {a) }}$ \\ Junko IWAHASHI, Hiromitsu YAMAGISHI, Izumi KAMIYA and Hiroshi P. SATO
}

\begin{abstract}
Discriminant analyses were done using 25-m grid data for slope angle, precipitation, peak ground acceleration, geology, curvature, geological structure, and slope aspect of affected areas by the 2004 heavy rainfall in July and the Mid Niigata Prefecture Earthquake in October to explain occurrence of landslides. Amount of contribution to landslides was estimated by discriminant for each parameter. The results are as follows. The slope angle is an important contribution factor, but in the case of the heavyrainfall, the precipitation contributes to landslides more than the slope angle. Remarkable differences of the contribution were observed in mud-rich turbidites of the Nishiyama stage and the Uonuma formation between the rain-driven failures and the earthquake-driven failures. The curvature showed larger contribution to the rain-driven failures than the earthquake-driven failures. The geology and geological structure showed large contribution to large landslides by the earthquake, and the slope aspect displays regional differences.

Key words : the July 132004 heavy rainfall, the Mid Niigata Prefecture Earthquake, landslide, GIS, discriminant analysis, slope angle

\section{和文要旨}

2004年（平成16年） 7 月の新潟豪雨および10月の新潟県中越地震によって，傾斜 5 度以上の丘陵地・山地に相当する中新世〜更

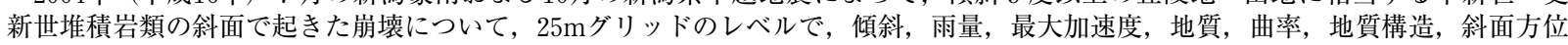
のGISデータを用いて判別分析を行った。判別分析によって，各パラメータの崩壊に対する寄与を評価した。その結果，傾斜は重要 なファクターであるが，豪雨による斜面崩壊では，傾斜以上に日雨量の寄与が大きいこと，西山階泥岩優勢夕ービダイト層と魚沼 層では豪雨と地震に於ける崩れやすさが異なっていたこと, 曲率の寄与は豪雨で大きいこと, 地質と地質構造の寄与は地震で起き た大崩壊の場合大きいこと，斜面方位の寄与には地域差があることなどが分かった。 キーワード：平成16年 7 月新潟豪雨, 新潟県中越地震, 斜面崩壊, GIS, 判別分析, 傾斜
\end{abstract}

\section{1.はじめに}

2004年10月23日に発生した新潟県中越地震（マグニ チュード6.8）の際，山古志村（現長岡市）を中心に多 くの斜面崩壊が発生した。中越地域では，梅雨前線の接 近に伴い2004年 7 月13日未明から始まった豪雨（牛山， 2004 ；以後 7 月豪雨と記載）によっても，多くの斜面崩 壊が起きており，隣接した似通った地層の分布域におい て，異なる誘因による数千力所に扔よぶ斜面崩壊の被害 を受けたことになる。本研究は, 中縮尺レベルのデータ の判別分析によって，7月豪雨㧍よび中越地震をトリ ガーとする斜面崩壞, 特に表層崩壊について，1）どの 要因が大きく寄与したか 2) 共通する要因はないか

3 ）今後の対策に関して何が重要なのかを評価し, 明ら かにする事を目的としている。

従来から, 特定の災害で起きた斜面崩壊の地形・地質 条件の調查は行われて打り（例えば釜井，1989; 西山・ 千木良, 2002), 中越地震による崩壊についても, 川邊 ほか (2005), 丸井ほか (2005), Chigira and Yagi (2006), 佐々木ほか (2006), 関口・佐藤 (2006), 八木ほか (2007)

\footnotetext{
※連絡著者/corresponding author

a) 国土地理院

Geographical Survey Institute

Geographical Survey Institute
テ305-0811 茨城県つくば市北郷 1 番

T 305-0811 茨城県つくば市北郷 1 番
Kitasato-1, Tsukuba, 305-0811 JAPAN

b) 新渴大学自然科学系

Niigata University
}

等がある。また, GISを利用して大型の地すべりの地形・ 地質条件や危険度を解析した研究は, 海外のものを中心 に多くある（例えばCarrara et al., 1991 ; Guzzetti et al., 1999 ; Iwahashi et al., 2001)。しかし，これほど隣接し た地域で起こった，似通った地質条件下の，異なるトリ ガーによる斜面崩壊を，GISを利用して定量的に解析し た研究は, 本研究の先行研究 (山岸ほか, 2005 ; Yamagishi et al., 2006 ; 岩橋ほか，2006）を除いてはない。

本研究では, 厳密に斜面の安定性を評価するために, 先行研究で行った, 単位斜面毎の崩壊個数や面積率の調 查を一歩進め, それぞれの地層によって異なる傾斜分布 や降雨量の偏りを考慮した分析を行った。具体的には, 中新世〜更新世堆積岩類（分布がごく限られた地層は除 く）の地質デー夕に, 傾斜や雨量のデー夕等も加えて判 別分析を行い，標準化された正準判別関数係数の值に よって, 崩壊の条件を評価した。判別分析は多変量解析 の一種であり, 定量的な説明変数を用いて全サンプルを 崩壊・非崩壊といったグループに分類する教師付きの分 類手法である（武田・今村，1996）。この判別のための 判別関数係数の大きさによって, ある項目 (説明変数) が崩壞，非崩壊の判別に寄与しているか否かを評価でき る。判別分析は, $25 \mathrm{~m}$ グリッドの格子点をサンプルとし て行った。 
崩壊地の位置デー夕は，中越地震については，平成17 年12月に国土地理院から公表された「平成16年新潟県中 越地震 $1: 25,000$ 災害状況図」(以下, 災害状況図とい う）から「斜面崩壊地（大) (小)」(鈴木ほか，2005）の データを取り出して利用した。7 月豪雨の崩壊地デー夕 は, Yamagishi et al.（2005）を利用した。どちらも,1： 10,000前後の縮尺の空中写真を判読し, $1: 25,000$ 地形 図を基図として作成された図である。両者の範囲は一部 重なっているが，災害状況図のデータのうち，7月豪雨 による崩壊の可能性があると考えられた少数の崩壞は, 統計解析の対象から削除した。

7 月豪雨抢よび中越地震による小規模な斜面崩壊につ いては, Yamagishi et al. (2005), 斉藤（2007）, 関口・ 佐藤（2006）の報告では，ほとんどが表層崩壊であると 推測している。豪雨による表層崩壊は, 全国的にも数百 $\mathrm{m}^{2}$ 程度の規模が多いといわれており（道上，1990），小 規模な表層崩壊は，身近な災害である。一方，中越地震 の大崩壊には, 地すべり性崩壊もかなり混じっていると 推測されている（鈴木ほか，2005；関口・佐藤，2006）。 従って, 中越地震のケースでは, 小崩壊（災害状況図の 「斜面崩壞地 (小) 」; 滑落崖の長さが数十 $\mathrm{m}$ 程度までの 小規模な崩壊) と, それ以上の大崩壊 (災害状沉図の「斜 面崩壊地（大）」; 小崩壊より規模が大きく, 多くの場合 滑落崖と堆積部を判読できる）を分けて分析した。7 月 豪雨については全体に規模が小さく, 中越地震のケース と比較するとほとんどは小崩壊であるとみなされる。

調查範囲は地形, 地質, 崩壊位置データが得られた図 - 1 の範囲である。本文では, 図-1のように, 調査範 囲を, 7月豪雨については出雲崎地域, 栃尾地域と, 中 越地震については山古志地域と呼ぶ。出雲崎地域と栃尾 地域は少し場所が離れており西山丘陵と東山丘陵に分か

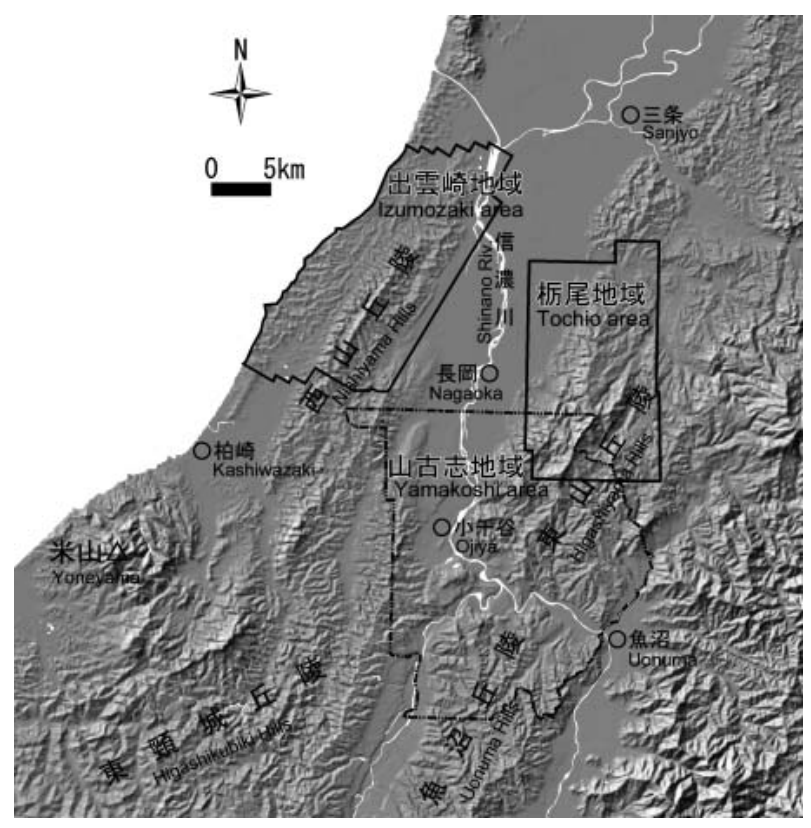

図ー 1 調査範囲およびその周辺

Fig. 1 Study areas and their surroundings
れているため, 分析も分けて行った。山古志地域の大部 分は東山丘陵㧍よびこれに続く魚沼丘陵に含まれる。調 查範囲内の崩壊個数は, 7月豪雨では2113力所, 中越地 震では小崩壊が6987カ所, 大崩壊が733力所である。面 積率としては, 滑落崖（発生域）で計算すると, いずれ も数\%以下である。

傾斜等の地形量を計算するための標高データとして,

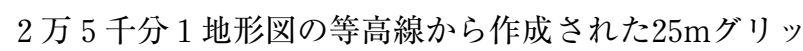
ド標高デー夕 (GISMAP TERRAIN; 北海道地図株式 会社）を利用した。 $25 \mathrm{~m}$ グリッドは中縮尺レベルに相当 する。例えば20度と計算された斜面でも，現地では，もっ と急な部分や平らな部分があるはずである。しかし，小 縮尺レベルとは異なり，尾根筋・谷筋といった地形の骨 格はきちんと捉えられている。

なお，判別分析を行う際は，傾斜 5 度以上の斜面で, なおかつ，「2.」に挙げる項目のデータが全て揃う斜面 に限定して行う。25mグリッドDEMからの計算で傾斜 5 度以上の斜面は, 抒㧍むね丘陵地・山地に相当する (岩 橋ほか, 2006)。

\section{2. 変数として利用した項目及びその概観}

\section{1 目的変数：崩壊・非崩壊グリッドデータ}

崩壊を 1 , 非崩壊を 0 とした $25 \mathrm{~m}$ グリッドデー夕を, 判別分析の目的変数として使用した。中越地震の場合, 災害状況図が，小崩壊については滑落崖の線描とケバで 描写されている（鈴木ほか，2005）。滑落崖の線描とケ バのラインデー夕に， $12.5 \mathrm{~m}$ のバッファを発生させた 後, $25 \mathrm{~m}$ グリッドの格子点がバッファと重なる点を崩壊, 重ならない点を非崩壊とした。中越地震の大崩壊につい ては, 発生域（滑落崖）と堆積域が別々のポリゴンデー 夕として表現されているため, 発生域のポリゴンに 12.5

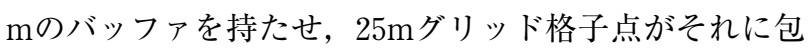
有されれば崩壊，されなければ非崩壊とした。7 月豪雨 の場合は, 崩壊地のポリゴンデー夕 (Yamagishi et al., 2005）を用いて, 中越地震の大崩壞と同様に， $12.5 \mathrm{~m}$ の

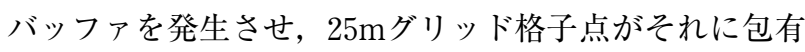
されれば崩壊，されなければ非崩壊とした。従って，7 月豪雨・中越地震共に, 崩壊グリッドとは崩壊発生域を 指す。

\section{2 連続值の説明変数と崩壊グリッドの比率の関係 \\ 2.2.1 傾斜}

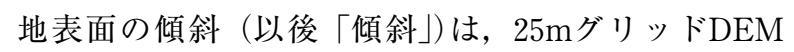
を用いて，ArcGIS (ESRI社) のSLOPEコマンドによっ て計算した。SLOPEコマンドは，ある点と隣接する 8 点の範囲 $(3 \times 3)$ の標高值を用いて傾向面の傾斜を求 めるものである。

図- 2 は, 出雲崎地域・栃尾地域 ( 7 月豪雨の崩壊) と山古志地域（中越地震の小崩壊 ·大崩壊）について, 崩壊グリッドの比率（\%）を 2 度刻みの傾斜毎に示した ものである。中越地震の場合, 特に大崩壊では, 急斜面 

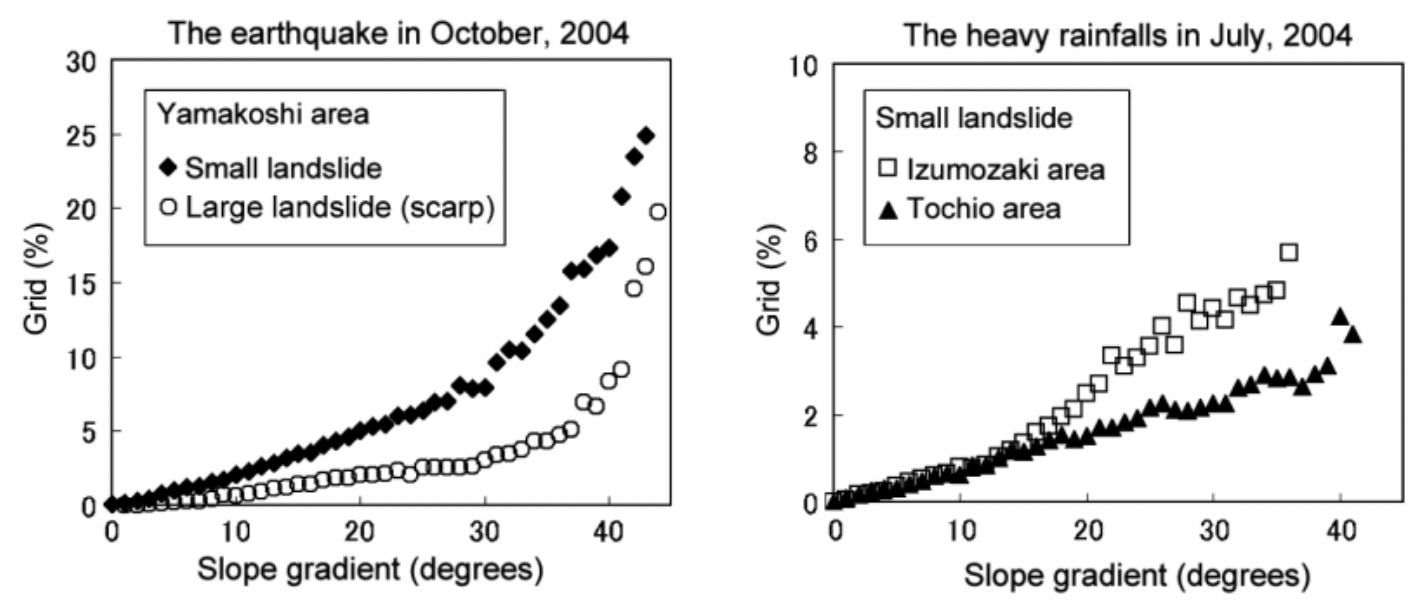

図ー2 傾斜毎の崩壊グリッドの比率（\%)

Fig. 2 The grid percentage of landslides to the slope gradient

で崩壊グリッド比率が急激に高くなる。ただし，緩斜面 ほど分布面積が大きく，急斜面はグリッド数としてはご く少なくなる。 7 月豪雨の場合は, 崩壊グリッドの比率 はかなり低くなるが，傾斜に比例している。なお，岩橋 ほか（2006）は，中越地震の小崩壊と，7月豪雨の崩壊 について, 斜面傾斜毎の崩壊発生率 $\left(\right.$ 個 $\left./ \mathrm{km}^{2}\right)$ を求め ているが，中越地震のケースでは，抄おむね，図-2 と 似たようなカーブを描き，7月豪雨のケースでは，崩壊 個数は傾斜が30度程度で頭打ちになっていた。急斜面で 崩壊発生率が頭打ちになる（岩橋ほか，2006）にもかか わらず崩壊グリッド比率は単調に増加する（図－2）と いう事は，7月豪雨による崩壊では，急斜面ほど崩壊の 規模が大きかった事を示している。

\subsection{2 日雨量}

7 月豪雨の雨量デー夕は, 2004年 7 月 13 日 1 時〜 24 時 までの日雨量を用い，気象デー夕（河島ほか，2005）か ら内挿して作成した。図-3は，2004年 7 月13日の日雨 量分布図である。日雨量 $300 \mathrm{~mm}$ 越えるエリアが, 出 雲崎町，長岡市（旧三島町・旧栃尾市・旧下田村）を中 心に分布している。なお，近隣の消防署の観測值（新潟 大学河島克久准教授のご厚意による）および気象庁アメ ダスによると，この日に多い所では時間雨量 $40 \mathrm{~mm}$ 以上 の豪雨が記録されている。

日雨量と崩壊グリッド比率の間には正の相関があり, 日雨量が大きい程, 崩壊グリッドの比率も高くなる（図 $-4)$ 。平均傾斜が他より高い日雨量带があれば，崩壊 グリッドの比率が日雨量の影響以上に高くなると考えら れるため, 各区間の平均傾斜も図 -4 に併記した。日雨 量 $100 \mathrm{~mm}$ 以上のゾーンで平均傾斜が数度以内の幅に一 定しており，傾斜のばらつきの影響が少ない出雲崎地域 のグラフからは, 日雨量が大きい程崩壊グリッドの比率 が高い傾向が, 非常に顕著に読みとれる。

\subsection{3 最大加速度}

中越地震によって斜面崩壊が起きたエリアは，計測震 度分布（末冨ほか, 2006）と比較すると, 震度 4 以上の

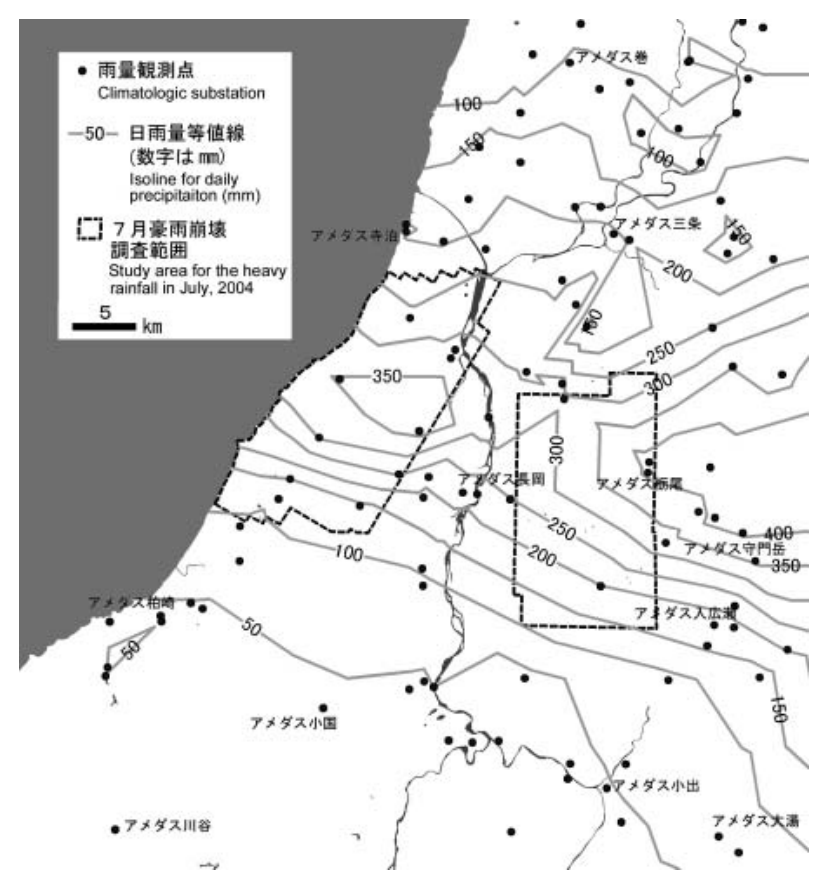

図一 32004 年 7 月13日の日雨量分布図（雨量值は河島ほか (2005) より)

Fig. 3 Daily precipitation on July13, 2004

範囲に収まっており, 震度 5 強以上の範囲（本研究の山 古志地域含む) で多発している。局所的な地震の摇れの 大きさは，地形・地盤条件によって強く左右されると考 えられるが, 末冨ほか $(2006,2007)$ は，ボーリングデー 夕を用いて平均 $\mathrm{S}$ 波速度を求め, 中越地震の強震観測点

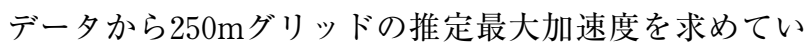
る。図－5は，末冨ほか（2006）のデー夕を利用して, 推定最大地震波加速度と崩壊グリッド比率の関係を求め たものである。図 -4 同様に, 各帯の平均斜面傾斜も併 記したが，最大加速度の計算には地形の情報も使われて いるため, 傾斜と負の相関が見られる。傾斜は崩壊グリッ ド比率と強い正の相関があるので, 平均傾斜の小さい ゾーン $\left(700 \mathrm{~cm} / \mathrm{s}^{2} \sim\right)$ では, 崩壊グリッド比率は低く なっている (図-5)。しかしながら， $500 \sim 700 \mathrm{~cm} / \mathrm{s}^{2}$ 

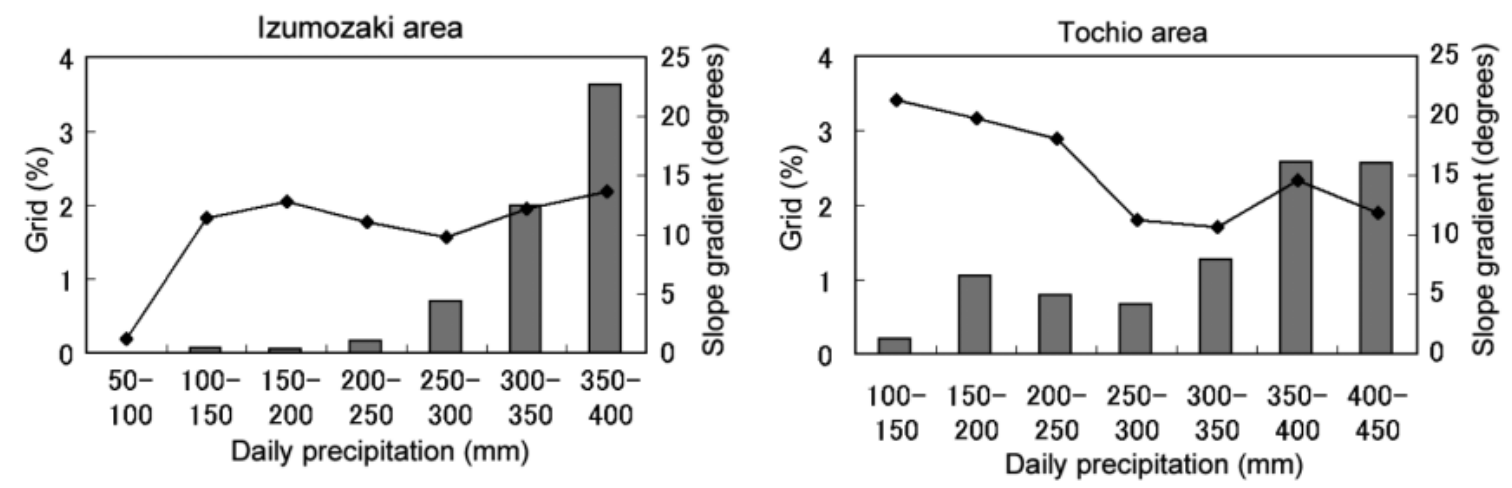

Grid percentage of landslides $\rightarrow-$ Mean value of slope gradient for each precipitation zone

図ー4 日雨量毎の崩壊グリッドの比率(\%) 黒折れ線は各ゾーン毎の平均傾斜角度

Fig. 4 The grid percentage of landslides to the daily precipitation
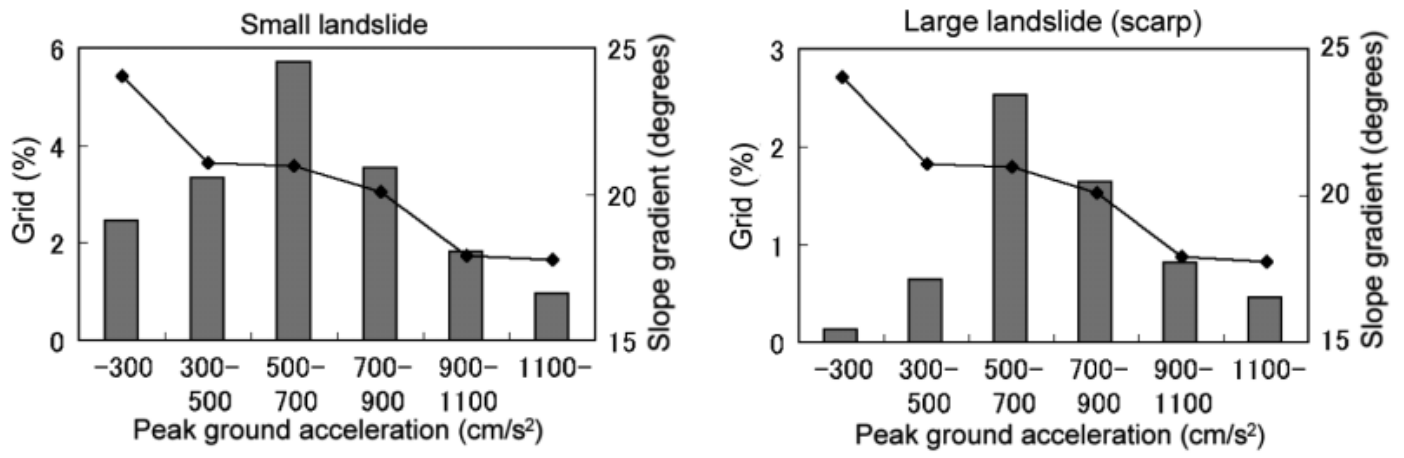

Grid percentage of landslides

Mean value of slope gradient for each acceleration zone

図－5 推定最大地震波加速度（末冨, 2006）毎の崩壊グリッドの比率 (\%) 黒実線は各ゾーン毎の平均傾斜角度。傾斜 5 度以 上の斜面のみ

Fig. 5 The grid percentage of landslides to the peak ground acceleration estimated by Suetomi, 2006 (slopes over 5 degrees only)

のゾーンまでは，小崩壊・大崩壊どちらのケースでも， 最大加速度が大きくなるほど崩壊グリッド比率も大きく なる傾向が見られ，仮に同じ傾斜の斜面であれば，受け る最大加速度が大きいほど，崩れやすいであろうことを 暗示している。

\section{2.4 曲率}

斜面の曲率（傾斜の変化率）は, 斜面の形状を決定し, 集水や地震波の増幅に影響を与える重要な条件である。 曲率のデータについては, 傾斜同様, ある点と隣接する 8 点の範囲 $(3 \times 3)$ の標高值を用いて, ArcGISのコ マンドによって水平・鉛直曲率を求めた。このコマンド はZevenbergen and Thorne（1987）に基づいており, 縦断・横断曲率をそれぞれ $3 \times 3$ 画素の範囲で計算する。 曲率を利用して斜面を評価するには, 縦断・横断曲率の 符号に基づて斜面型を 9 分類して傾向を見る方法（鈴 木, 1997 ; 岩橋ほか, 2006）と，曲率の值そのものを用 いる方法がある。本研究では, 曲率の值を用いて判別分 析を行った。

傾斜 5 度以上の斜面（丘陵地・山地斜面）についての, 崩壊グリッド比率と曲率の関係は, 図 - 6 の通りである。 7 月豪雨のケースでは, 谷地形 (水平曲率が負) の場合,
つまり，マイナスの值ほど崩壊グリッド比率が高くなる。 尾根地形，つまり水平曲率が正の場合では，崩壊グリッ ド比率はほぼ一定である。凸型斜面(鉛直曲率が負 ; ArcGISでは鉛直曲率については負の值が凸となる（駒沢 大田中靖講師私信))では, 崩壊グリッド比率はほぼ一定 か, 出雲崎地域の場合は, 曲率が小さくなると崩壊地の 割合が増える。凹型斜面 (鉛直曲率が正) の場合は, 出 雲崎地域・栃尾地域共, 曲率が大きくなるほど崩壊グ リッド比率が高くなる。中越地震のケースではもっとシ ンプルで, 水平・鉛直曲率とも, 絶対值が大きくなる程, 崩壊グリッドの比率が高くなる。特に小崩壊では, その 傾向が顕著である。

このように，曲率と崩壊グリッド比率の関係は単純で はないが，正準判別分析を行うに際しては，7月豪雨の ケースには主に曲率の值をそのまま使い（出雲崎地域の 鉛直曲率のみ, 曲率の絶対值), 中越地震のケースには, 曲率の絶対值を用いるのが適当と考えられる。

\section{3 連続値ではない説明変数（ダミー変数）}

この節では, 地質や斜面方位など, 連続值ではない変 数について説明する。このような変数は, 例えば北向き 斜面についてのデータの場合は, 北向きならグリッド值 

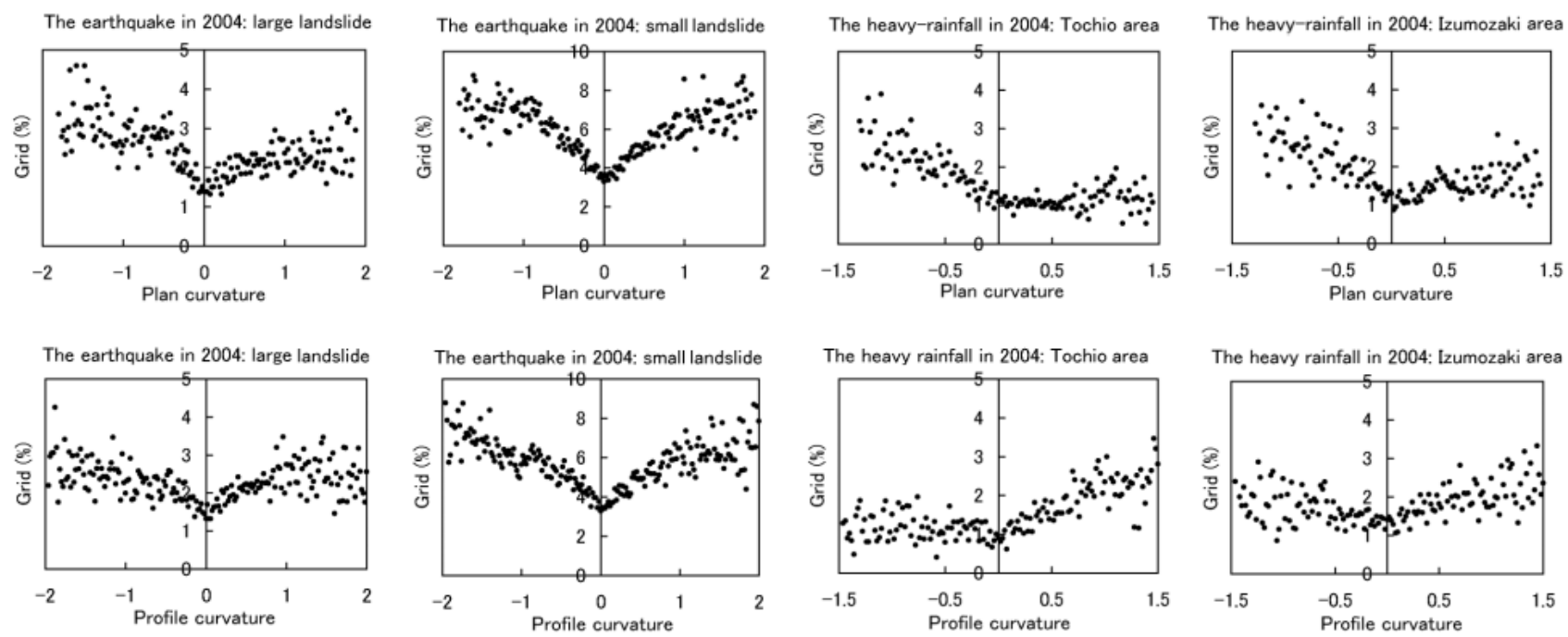

図ー6 曲率毎の小崩壊グリッドの比率 (\%) 傾斜 5 度以上の斜面のみ

Fig. 6 The grid percentage of small landslides to the curvature (slopes over 5 degrees only)

を 1 ，それ以外のグリッド值は 0 とするように，ある定 性的事項がyesかnoかについてのデータ（ダミー変数） を作成して分析を行った。

\subsection{1 地質}

地質（岩相）の違いが斜面崩壊の多少に影響を与える 事は, 広く知られている。7 月豪雨と中越地震の被害域 を比較するにあたって，この地方の地質図を接合した データを作成した。接合にあたっては，岩相分類的な特 徵が出るように留意した。利用した地質図は, 中越魚沼 地域の 5 万分の 1 数值地質図 (竹内ほか, 2004), 5 万分 の 1 地質図幅及び説明書「出雲崎 (小林ほか, 1993)」「三 条（小林ほか, 2001）」「柏崎（小林ほか, 1995)」である。 これらを接合するにあたって，図幅解説書の記載を元 に，凡例を再分類した。丘陵地・山地の大部分を占める 中新世〜更新世堆積岩類については, まず, 御山・魚沼 · 灰爪・西山・椎谷・寺泊・七谷・津川の各層および相当 層にまとめた。図 -7 は, 5 万分の 1 地質図からまとめ た各層の分布と, 褶曲軸・断層の分布である。それぞれ について, 時代が古く崩壊多発域からも外れている津川 層以外は，層相に基づいて細分した。なお，「砂岩」「泥 岩」等にまとめたものでも層相の変化があり, 細粒層が 混じったり磁が混じるものもある。層相の変化が比較的 そしいと推測されるのは, 塊状泥・塊状泥岩, シルト・ 砂質シルト岩である。本地域の堆積岩類は軟岩であり, 岩石とされている地層でも, ハンマーで削れたりボロボ ロ崩れたりするようなものが多い。このような凡例の再 構成によって，地質図の大部分は接合が可能になった。 一部食い違う部分 (段丘面の区分や, 三条図幅の魚沼層 砂層と中越数值地質図の和南津層など）は, 調査年代の 新しい地層や面積が大きい地層を優先して, 属性の付け 替えを行った。

表- 1 は, 各 5 万分の 1 地質図の凡例と, 本研究で使 用した地質データの対照表である。なお, 分析の際には,
後述の地質構造のデータが得られる中新世〜更新世堆積 岩類の分布域のみで分析を行った。また, 調査地域内で 分布がごく限られた地層は分析に用いていない。判別分 析に用いた地層は，表－1の中でアスタリスク（*)を 表示している。

\subsection{2 地質構造}

受け盤・流れ盤等の地質構造によって, 斜面の安定が 異なることは広く知られている。鈴木（2000）は, 斜面 傾斜と地層面傾斜（dip）の関係によって, 斜面を, 水 平盤, 柾目盤, 平行盤, 逆目盤, 垂直盤, 受け盤の 6 種 類に分類し，それぞれの安定性を評価した。岩橋ほか （2006）は，地層の傾斜方位が比較的そろっている地域 について, 受け盤・流れ盤を大まかに分類して崩壊個数 を調べたが，本論では，斜面傾斜が 5 度以上（おおむね 丘陵・山地に相当）の中新世〜更新世堆積岩類分布域に ついて，5万分の 1 地質図に記載された走向・傾斜デー 夕を用いて，鈴木（2000）の手法に基づき，もう少し厳 密な推定地質構造分布図を作成した。

最初に, 5 万分の 1 地質図に記載されている地層面の 走向・傾斜（以後, 斜面傾斜との混乱を避けるためdip と呼ぶ）のデータから, 走向とdipの值を属性に持つポ イントデータを作成した。斜面の走向の值から, 地層面 傾斜方位を求め，8方位に分類し，それを点デー夕の属 性として, ArcGISによってティーセンポリゴンを作成 した。ティーセンポリゴンとは，隣り合う点間の垂直二 等分線をポリゴン境界として, 点データをポリゴンに拡 大したものである。地層面傾斜方位は背斜軸・向斜軸で 変化するものと考え，ティーセンポリゴンが背斜軸・向 斜軸に合うように界線の手直しを行った。ティーセンポ リゴンの属性值と, 地表傾斜方位（8 方位）の関係から, 斜面を, 流れ盤, 受け盤, 走向斜面 (判別不能) に分類 した。流れ盤は, dip と斜面傾斜の関係から，鈴木 (2000) に基づき，さらに柾目盤・平行盤・逆目盤に細分した。 
表一 1 本研究地質データ凡例と 5 万分の 1 地質図凡例の対照表

Table 1 Legends for the geological data in contrast with $1: 50,000$ scaled geological maps

\begin{tabular}{|c|c|c|c|c|c|c|}
\hline 年代 & \multicolumn{2}{|r|}{ 本研究地質データ凡例 } & 中越魚沼（竹内ほか，2004） & 三条（小林ほか, 2001） & 柏崎（小林ほか, 1995） & 出雲崎（小林ほか, 1993） \\
\hline \multirow{2}{*}{$\begin{array}{l}\text { 更 } \\
\text { 新 } \\
\text { 世 } \\
\sum_{\text {完 }} \\
\text { 世 }\end{array}$} & 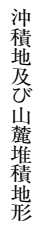 & $\begin{array}{l}\text { 盛地 } \\
\text { 砂丘·海浜 } \\
\text { 現河床·氾濫原·後背 } \\
\text { 湿地·海岸野 } \\
\text { 自然堤防 } \\
\text { 崩土·地すべり堆積物 } \\
\text { 崖錐・扇状地 }\end{array}$ & \begin{tabular}{l}
\multicolumn{1}{c}{-} \\
- \\
河道及び後背湿地堆積物 \\
自然堤防堆積物 \\
古期崩積および地すべり堆 \\
積物 \\
崖錐堆積物・扇状地堆積物
\end{tabular} & $\begin{array}{l}\text { 盛地 } \\
\text { 海浜堆皘物, 砂丘堆皘物 } \\
\text { 河床堆積物, 後背湿地堆積 } \\
\text { 物, 旧河道堆積物 } \\
\text { 自然堤防堆積物 } \\
\text { 地すべり堆積物 } \\
\text { 扇状地・崖錐堆積物 }\end{array}$ & $\begin{array}{c}- \\
\text { 新期・旧期砂丘堆積物 } \\
\text { 現河床堆積物, 氾濫原堆積 } \\
\text { 物・河道及び後背湿地堆積 } \\
\text { 物然堤防堆積物 } \\
- \\
- \\
- \\
-\end{array}$ & $\begin{array}{ll}\text { 砂丘 } & - \\
\text { 沖積層 } & \\
& \\
& - \\
& - \\
& -\end{array}$ \\
\hline & $\begin{array}{l}\text { 段 } \\
\text { 乒 }\end{array}$ & $\begin{array}{l}\text { 完新世段乒 } \\
\text { 位・段丘 } \\
\text { 高位段丘 }\end{array}$ & $\begin{array}{l}\text { 最低位段丘堆積物 } \\
\text { 低 位 II · 低 位 I · 中 位 II · } \\
\text { 中位 I 段兵堆積物 } \\
\text { 高位 II ·高位 I 段丘堆積物 }\end{array}$ & 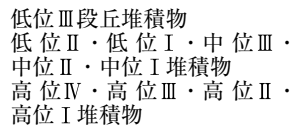 & $\begin{array}{l}\text { 低位· 中位 II · 中位 I 段 丘 } \\
\text { 堆積物 } \\
\text { 高位段丘堆積物 }\end{array}$ & $\begin{array}{l}- \\
- \\
-\end{array}$ \\
\hline $\begin{array}{l}\text { 更 } \\
\text { 新 } \\
\text { 世 }\end{array}$ & $\begin{array}{l}\text { 御 } \\
\text { 揩 }\end{array}$ & 砂優勢* & 御山層及び西層 & 御山層 & 大坪層, 田沢層 & 田沢層 \\
\hline \multirow[b]{3}{*}{$\begin{array}{l}\text { 鮮 } \\
\text { 新 } \\
\text { 世 }\end{array}$} & 魚 & $\begin{array}{l}\text { 砂優勢* } \\
\text { シルト* } \\
\text { 塊状泥 }\end{array}$ & $\begin{array}{c}\text { 魚沼層砂シルト相・砂シル } \\
\text { 相・砂相 } \\
\text { 魚沼層海成シルト相 } \\
\quad-\end{array}$ & $\begin{array}{c}\text { 魚沼層礫，礫・砂・泥 } \\
- \\
- \\
\text { 魚沼層海成泥 }\end{array}$ & 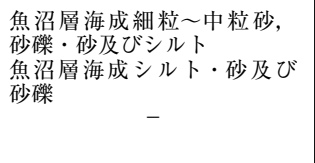 & 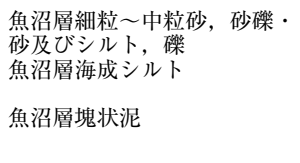 \\
\hline & $\begin{array}{l}\text { 灰 } \\
\text { 爪層 }\end{array}$ & 砂岩 & $\begin{array}{l}\text { 灰爪層砂質シルト岩及び砂 } \\
\text { シル細層 }\end{array}$ & 灰爪層砂質シルト岩 & $\begin{array}{l}\text { 灰爪層石灰啠砂岩及び細粒 } \\
\text { 砂・海成細粒〜粒砂 } \\
\text { 灰爪層細粒砂・砂質シルト } \\
\text { 岩・泥岩及び砂岩泥岩層, } \\
\text { 砂質シル卜岩及ひ砂質シル } \\
\text { 卜岩砂岩互層 }\end{array}$ & $\begin{array}{l}\text { 灰爪層石灰質砂岩及び細粒 } \\
\text { 灰爪層細粒砂・砂質シルト } \\
\text { 岩・泥岩及び砂岩泥岩層 }\end{array}$ \\
\hline & $\begin{array}{l}\text { 西 } \\
\text { 㾬 } \\
\end{array}$ & $\begin{array}{l}\text { 砂岩* } \\
\text { 砂岩優勢タービダイト* } \\
\text { 砂質シルト岩* } \\
\text { 泥岩 } \\
\text { 泥岩優勢タービダイト* } \\
\text { 塊状泥岩* }\end{array}$ & 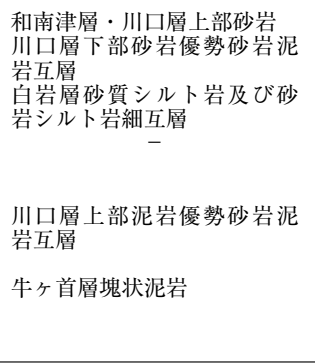 & $\begin{array}{l}\text { 魚沼層砂 } \\
\text { 牛ヶ首層砂岩泥岩互層 } \\
\text { 白岩層砂質シルト岩 } \\
\qquad- \\
\text { 西山層砂岩泥岩互層 } \\
\text { 西山層青緑色塊状泥岩, 牛ヶ } \\
\text { 首層青緑色泥岩 }\end{array}$ & 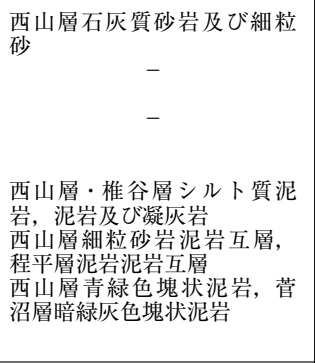 & $\begin{array}{c}- \\
- \\
- \\
- \\
\text { 西山層砂岩泥岩互層 } \\
\text { 西山層青緑色塊状泥岩 }\end{array}$ \\
\hline $\begin{array}{l}\text { 中 } \\
\text { 新 } \\
\text { 伟 } \\
\text { 鮮 } \\
\text { 新 }\end{array}$ & 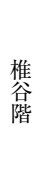 & $\begin{array}{l}\text { 砂岩* } \\
\text { 砂岩優勢タービダイト* } \\
\text { 泥岩優勢 } \\
\text { 塊状泥岩* }\end{array}$ & $\begin{array}{l}\text { 荒谷層砂岩及び砂岩泥岩互 } \\
\text { 層 } \\
\text { 荒谷層泥岩優勢砂岩泥岩互 } \\
\text { 層谷層塊状泥岩 }\end{array}$ & $\begin{array}{l}- \\
\text { 椎谷層黒色泥岩及び砂岩泥 } \\
\text { 岩曾 } \\
\text { 荒谷層黑色泥岩 }\end{array}$ & $\begin{array}{c}- \\
\text { 椎谷層泥岩泥岩互層及び砂 } \\
\text { 岩 } \\
- \\
-\end{array}$ & $\begin{array}{c}\text { 椎谷層厚層砂岩 } \\
\text { 椎谷層砂岩泥岩互層及び厚 } \\
\text { 層砂岩 } \\
- \\
- \\
-\end{array}$ \\
\hline \multirow{3}{*}{$\begin{array}{l}\text { 中 } \\
\text { 新 } \\
\text { 世 }\end{array}$} & $\begin{array}{l}\text { 寺 } \\
\text { 泊 } \\
\text { 階 }\end{array}$ & $\begin{array}{l}\text { シルト岩 } \\
\text { 泥岩優勢タービダイト } \\
\text { 塊状泥岩 }\end{array}$ & $\begin{array}{c}\text { 鳥屋ガ峰層泥岩岩塊 } \\
- \\
\text { 猿倉岳層硬質頁岩・砂岩頁 } \\
\text { 岩層 }\end{array}$ & $\begin{array}{c}\text { 寺泊層砂岩泥岩互層 } \\
-\end{array}$ & $\begin{array}{c}\text { 寺泊層黒色泥岩及び細粒砂 }^{-} \\
\text {岩泥岩層 } \\
-\end{array}$ & $\begin{array}{l}\text { 寺泊層黒色泥岩及び細粒砂 }^{-} \text {岩泥否 } \\
\text { - }\end{array}$ \\
\hline & $\begin{array}{l}\text { 妄 } \\
\text { 骝 }\end{array}$ & $\begin{array}{l}\text { 泥岩優勢 } \\
\text { 塊状泥岩 }\end{array}$ & $\begin{array}{c}- \\
\text { 半蔵金層塊状泥岩 }\end{array}$ & $\begin{array}{c}\text { 七谷層暗灰色泥岩・硬質頁 } \\
\text { 岩・凝灰岩 } \\
-\end{array}$ & $\begin{array}{l}\text { 七谷層硬質頁岩及び酸性火 } \\
\text { 山岩類 } \\
-\end{array}$ & $\begin{array}{l}\text { 七谷層硬質頁岩及び酸性火 } \\
\text { 山岩類 } \\
\quad-\end{array}$ \\
\hline & \multicolumn{2}{|c|}{ 津川階 } & $\begin{array}{l}\text { 八海山礫岩部層, 下長崎碟 } \\
\text { 岩頁岩部層 }\end{array}$ & - & - & - \\
\hline \multirow[t]{3}{*}{$\begin{array}{l}\text { 中 } \\
\text { 新 } \\
\text { 世 } \\
\text { 鮮 } \\
\text { 新 } \\
\text { 世 }\end{array}$} & \multicolumn{2}{|c|}{ 溶岩·火砕岩 } & 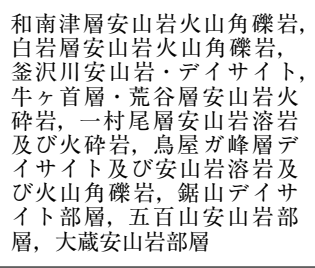 & $\begin{array}{l}\text { 牛ヶ首層デイサイト質火砕 } \\
\text { 岩 }\end{array}$ & 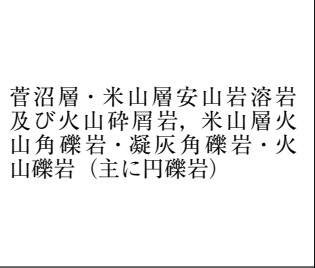 & - \\
\hline & \multicolumn{2}{|c|}{ 凝灰岩 } & $\begin{array}{l}\text { 栖吉層主部, 西名層デイサ } \\
\text { イ } \\
\text { 溶岩 }\end{array}$ & $\begin{array}{l}\text { 七谷層流紋岩·凝灰岩, 緑 } \\
\text { 色凝灰岩 }\end{array}$ & - & - \\
\hline & \multicolumn{2}{|c|}{ 貫入岩 } & 流紋岩・安山岩 & - & - & - \\
\hline $\begin{array}{l}\text { 生中 } \\
\text { 代: } \\
\text { 古 }\end{array}$ & \multicolumn{2}{|c|}{ 中·古生層 } & 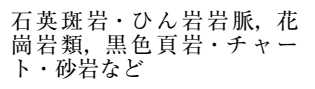 & - & - & - \\
\hline
\end{tabular}

* : 判別分析に利用した項目Items used to the discriminant analysis 


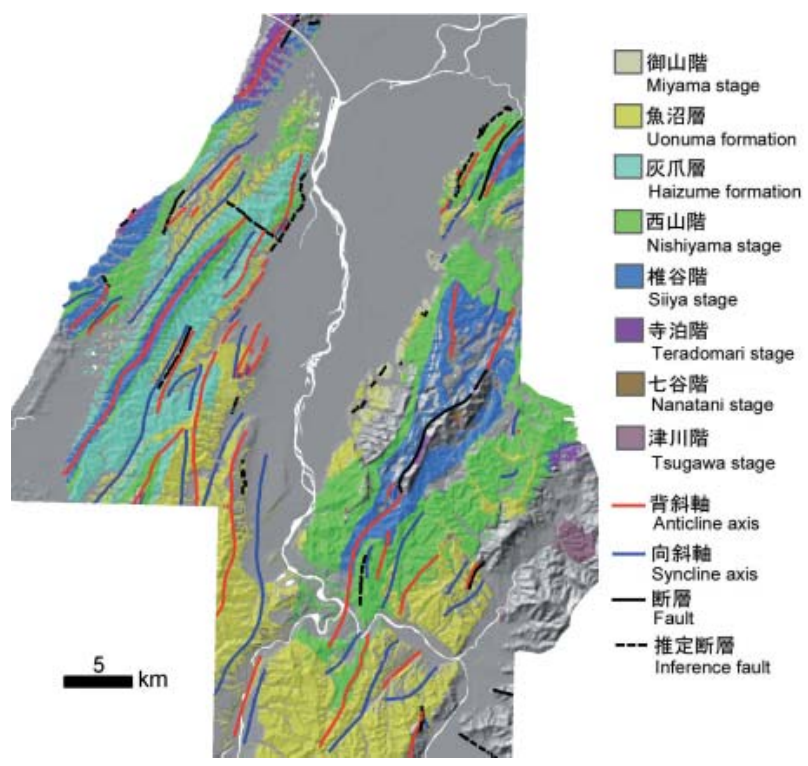

図- 7 中新世〜更新世堆積岩類の分布と褶曲軸・断層の分 布（小林ほか, $1993 \cdot 1995 \cdot 2001$; 竹内ほか, 2004 から編集)

Fig. 7 Distribution of Miocene to Pleistocene sedimentary rocks, fold axes and faults (compiled from Kobayashi et al., 1993, 1995, 2001, Takeuchi et al., 2004)

Dipのデータは，計測点のGISデータに地層傾斜角を属 性として与え，補間法の1つであるIDW（Inverse Distance Weighted）で補間計算したものである。この補 間計算においては，断層あるいは不整合面の上下で著し く走向方位が変化する箇所があればバリアラインに設定 するべきであるが，本地域では，不整合面の上下では走 向方位が変化していないため，断層のみをバリアライン とした。また，水平盤・平行盤の分類には \pm 3 度の幅を 持たせた。さらに， dipの大きさにより斜面崩壊の起き 方に違いがあったと考えられるため（岩橋ほか，2006； Yamagishi et al., 2006)，受け盤は，dipが40度以上の斜 面と 40 度以下の斜面に分けた。なお流れ盤については， 柾目盤等に細分する際，すでにdipの值を利用している。

地層の走向・傾斜計測点から $1 \mathrm{~km}$ のバッファを発生 させ,バッファが 3 つ以上重なっていないエリアは, デー 夕不十分として削除した。受け盤・流れ盤等の判定がで きない斜面（走向斜面）も，データから省いた。なお， 本調査地域には，垂直盤を示唆するデー夕はない。

以上の通り，中新世〜更新世堆積岩類の 5 度以上の斜 面のうち，地質図から走向・傾斜のデータが得られた斜 面を，水平盤，柾目盤，平行盤，逆目盤， $\operatorname{dip} 40$ 度未満 の受け盤，dip40度以上の受け盤の 6 種類に分類した（図 $-8)$ 。判別分析は，図-8 で示される地質構造のデー 夕が得られなかった斜面は省いて行った。

\subsection{3 斜面方位}

特定の向きの斜面で崩壊密度が高い現象が見られたと いう報告は多いが（たとえば沖村，1996；柴原，2001； 本多，2006)，地域や災害によって卓越方位が異なる上

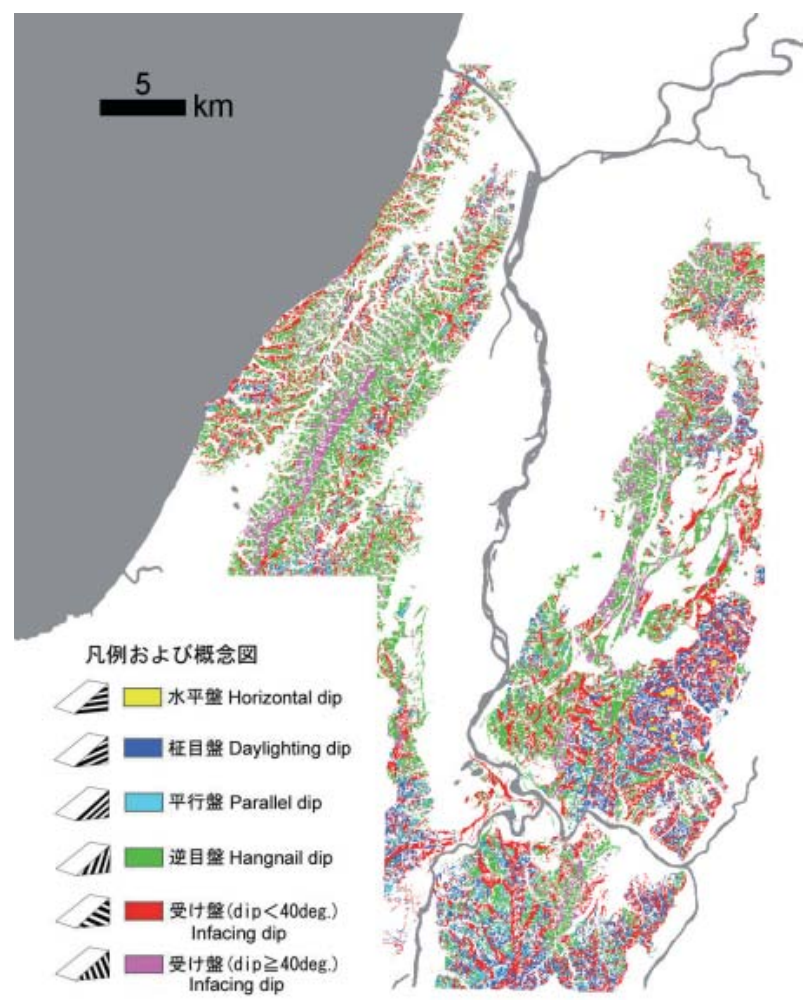

図－8 推定地質構造分布図（中新世～更新世堆積岩類, 5 度以上の斜面のみ)

Fig. 8 Estimated geological structure (slopes over 5 degrees of Miocene to Pleistocene sedimentary rocks only)

に，その原因は斜面の凍結・融解，植生，卓越水平加速 度方位と元の斜面の関係（横山・菊山，1997）など様々 に推測されており，斜面方位は，崩壊への寄与の理由が 一定でないパラメータである。さりとて崩壊・非崩壊を 判別する重要なパラメータの 1 つであることは明らかで, 無視できない。調查地域の中新世〜更新世堆積岩類分布 域の，傾斜 5 度以上の斜面（丘陵地・山地）について，8 方向の斜面方位を求め，デー夕を作成した。

中越地震で起きた斜面崩壊の個数は，南あるいは南東 斜面で多いことが報告されている（岩橋ほか，2006；本 多，2006；佐々木ほか，2006）。東向きの成分について は地質構造が関係するのではないかと推測されているが (岩橋ほか，2006），南向きで多かった理由は，現状では 不明である。本研究では崩壊地は個数ではなく崩壊源の グリッドデータとして扱っているが，この傾向は斜面方 位毎の崩壊グリッド比率に於いても同じである(図－9）。 中越地震のケースでは，大崩壊は傾向が弱いが，少なく とも小崩壊については南または南東優位の傾向が非常に はっきりしている。7 月豪雨についても斜面方位による 崩壊密度の差があり，出雲崎地域では北東および南西斜 面で多く，栃尾地域では東斜面で多い。

豪雨時の斜面崩壊に，方位毎の差が出る理由の 1 つと して，Pike and Sobieszczhk（2007）は風向を挙げてい る。ただし, 出雲崎周辺の気象データ（新潟大学河島克 
The earthquake in October, 2004
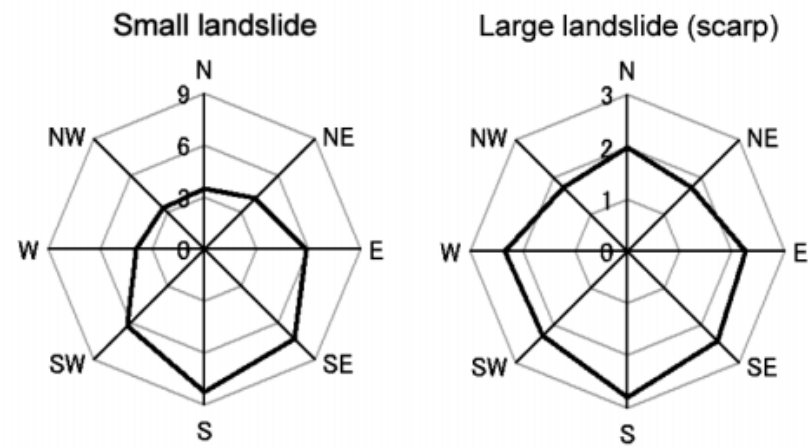

The heavy rainfall in July, 2004

Izumozaki area
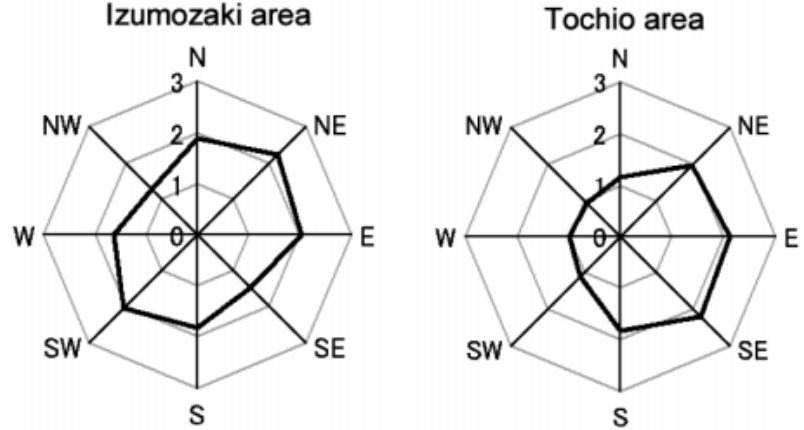

図－9＼cjkstart方位毎の崩壊グリッドの比率 (\%)

Fig. 9 The grid percentage of landslides to the slope aspect

久准教授のご厚意による）から,7月豪雨のピーク時には, 平均風速 $5 \mathrm{~m}$ 程度の西風が吹いていたと推測されるが, 西斜面だけに多いという傾向は出ていない。現時点の結 論としては，原因は定かでないが，7月豪雨の斜面崩壊 の密度は，方位毎の差はあったとだけ言わざるを得ない。 なお，傾斜や日雨量，曲率，地質構造の影響を無視して 独立に斜面方位を見る際は，日照や植生・表土層厚の偏 り, 豪雨の場合は降雨の方位毎の偏り（もし存在すれば), 地震の場合は摇れの方位の偏りなどを総合して見る必要 があろう。

\section{3. 解析結果およびその解釈}

傾斜, 日雨量, 曲率または曲率の絶対値, 地質, 地質 構造，斜面方位のデータを用いて正準判別分析を行い， 判別関数係数を求めると共に, 崩壊・非崩壊の別に対す るそれぞれの変数の寄与を評価した。分析には統計解析 ソフトSPSS (SPSS Inc.)を用いた。変数の投入はステッ プワイズ法で行った。

判別分析の結果は, 表- 2 の通りである。正答率は 7 割前後である。寄与の順位については，連続值の変数の みでなくダミー変数も混じっている（すべてのダミー值 の係数に同じ值を加えても同様の結果を得る事ができ る）ため，判別関数係数から直接推測することができな い。そのため，すべての説明変数を投入して分析した正 答率（一番下の欄）と，ある説明変数を抜いて分析した
正答率の差から，寄与順位を推測した。まず崩壊地の正 答率の差を見て，それが同じか近い場合は全体の正答率 の差を見ながら順位付けしたものである。なお，同じカ テゴリの中であれば，正規化正準判別関数係数 (表 -2 ) の值によって，寄与の大小を比較することが可能である。

\section{1 寄与の順位}

7 月豪雨による崩壊では, 出雲崎地域, 栃尾地域とも, 日雨量の寄与が最も大きい (表- 2$)$ 。次に寄与が大き いのは傾斜である。共通なのはここまでで，それ以下の 順位は，地域によって差が出た。出雲崎地域では地質の 寄与が次いで大きく，曲率が地質に次ぐ。斜面方位は多 少寄与しているが，地質構造はほとんど寄与していない。 栃尾地域では，正答率の差に負の值が出てくる（ない方 が正答率が上がったことを示している）ケースもあり， 日雨量と傾斜以外は，総じて寄与が小さい。崩壊地の正 答率の差から見て，日雨量と傾斜の次は，水平曲率，斜 面方位，地質構造の順であろう。

中越地震による崩壊では，小崩壊と大崩壊で明瞭な差 が出た。小崩壊では，傾斜の寄与が最も大きく，斜面方 位がそれに次いだ。斜面方位の次は，地質，曲率の絶対 值の順である。地質構造はほとんど寄与しておらず，最 大加速度は，寄与が無いとして，ステップワイズ法の段 階で削除された。大崩壊には地質の寄与が最も大きい。 次いで傾斜, その次は地質構造である。地質構造は, 小 崩壊や 7 月豪雨の崩壊には上記のと㧍り寄与が小さいが, 大崩壊のみ優位な差が出た。最大加速度は，大崩壊には 寄与している。曲率の絶対值, 斜面方位は寄与が小さかっ た。

\section{2 判別関数係数から見える傾向}

\subsection{1 連続值の変数}

連続值の変数の判別関数係数を比較すると, 地震の場 合，傾斜の係数が最も大きく，傾斜が最も崩壊・非崩壊 の判別に寄与している。最大加速度は，大崩壊には崩壊 地の判別に有効であるが，その影響は傾斜と比べて 1 / 5 以下である。豪雨による斜面崩壊では，傾斜よりも日 雨量の寄与が大きい。

曲率も無視できない変数であるが，傾斜や雨量ほど寄 与は大きくない。豪雨のケースの方が，曲率の寄与は大 きい。水平曲率に関しては, 出雲崎・栃尾どちらでも, マイナスの值になるほど崩れやすかったことがわかる

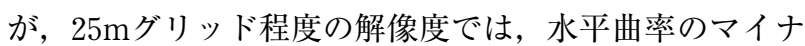
スの度合いが大きい場所は大きな谷筋であり，水が集 まってくる斜面である。鉛直曲率に関しては地域差が出 た。 $25 \mathrm{~m}$ の解像度では, 鉛直曲率の值が大きい場所は, 斜面の脚部に多く，值がマイナスで小さい場所は，尖っ た尾根付近に多い。全体に，斜面の脚部が崩れやすかっ たが，出雲崎地域では，尾根付近でも多少崩れやすかっ たことになる。地震では，曲率の絶対值が大きいほど崩 れやすいという傾向が出ている。 
表一2 各説明変数の正規化正準判別関数係数および寄与順位

Table 2 Standardized canonical discriminant function coefficients and ranks for contribution for each variable

\begin{tabular}{|c|c|c|c|c|c|c|c|c|c|c|c|c|c|c|c|c|c|}
\hline & \multicolumn{8}{|c|}{ 中越地震（山古志地域）the Mid Niigata Prefecture Earthquake（Yamakoshi area） } & \multicolumn{8}{|c|}{ 7月豪雨（小崩壊） the2004Niigata heavy rainfall（small landslide） } \\
\hline & & \multicolumn{4}{|c|}{\begin{tabular}{|c|} 
小崩壊small landslide \\
\end{tabular}} & \multicolumn{4}{|c|}{ 大崩壊large landslide (scarp) } & \multicolumn{4}{|c|}{ 栃尾地域Tochio area } & \multicolumn{4}{|c|}{\begin{tabular}{|c|} 
出雲崎地域Izumozaki area \\
\end{tabular}} \\
\hline & & \multirow{2}{*}{$\begin{array}{c}\text { Discriminant } \\
\text { function } \\
\text { coefficient } \\
\end{array}$} & \multicolumn{2}{|c|}{$\begin{array}{c}\text { Decrease in hit rate } \\
\text { without the variable }(\%)\end{array}$} & \multirow{2}{*}{ Rank } & \multirow{2}{*}{$\begin{array}{l}\text { Discriminant } \\
\text { function } \\
\text { coefficient }\end{array}$} & \multicolumn{2}{|c|}{$\begin{array}{l}\text { Decrease in hit rate } \\
\text { without the variable }(\%)\end{array}$} & \multirow{2}{*}{ Rank } & \multirow{2}{*}{$\begin{array}{c}\text { Discriminant } \\
\text { function } \\
\text { coefficient }\end{array}$} & \multicolumn{2}{|c|}{$\begin{array}{c}\text { Decrease in hit rate } \\
\text { without the variable }(\%)\end{array}$} & \multirow{2}{*}{ Rank } & \multirow{2}{*}{$\begin{array}{c}\text { Discriminant } \\
\text { function } \\
\text { coefficient }\end{array}$} & \multicolumn{2}{|c|}{$\begin{array}{c}\text { Decrease in hit rate } \\
\text { without the variable }(\%)\end{array}$} & \multirow{2}{*}{ Rank } \\
\hline & & & whole & landslide & & & whole & landslide & & & whole & landslide & & & whole & landslide & \\
\hline \multirow{7}{*}{ 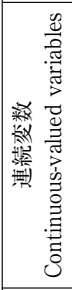 } & 傾斜Slope gradient & 0.599 & 0.9 & 5.3 & (1) & 0.603 & 2.4 & 3.4 & (2) & 0.520 & 0.7 & 3.8 & (2) & 0.552 & 3.4 & 2.2 & (2) \\
\hline & 最大加速度Peak ground acceleration & null & - & - & null & 0.108 & 0.1 & 0.2 & (4) & - & - & - & - & - & - & - & - \\
\hline & 日雨量Daily precipitation & - & - & - & - & - & - & - & - & 0.622 & 0.3 & 7.6 & (1) & 0.646 & 1.2 & 9.1 & (1) \\
\hline & 水平曲率Plan curvature & - & - & - & - & - & - & - & - & -0.251 & -0.6 & 1.5 & (3) & -0.226 & 0.8 & 0.3 & (5) \\
\hline & 鉛直曲率Profile curvature & - & - & - & - & - & - & - & - & 0.219 & -0.5 & 0.4 & (6) & - & - & - & - \\
\hline & \begin{tabular}{|l} 
水平曲率の絶対值 \\
Absolute value of plan curvature
\end{tabular} & 0.134 & 0.0 & 0.8 & (5) & 0.050 & 0.0 & 0.0 & (7) & - & - & - & - & - & - & - & - \\
\hline & $\begin{array}{l}\text { 鉛直曲率の)絶対値 } \\
\text { Absolute value of profile curvature }\end{array}$ & 0.157 & 0.1 & 0.9 & (4) & 0.132 & 0.0 & 0.2 & (5) & - & - & - & - & 0.181 & 0.3 & 0.5 & (4) \\
\hline \multirow{12}{*}{ 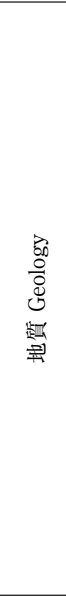 } & 御山階(砂優勢) Miyama S. (sandrich) & - & \multirow{12}{*}{2.8} & & & - & & & & null & & & & null & & & \\
\hline & 魚沼層(砂優势) Uonuma F. (sandrich) & -0.411 & & & & -0.579 & & & & 0.136 & & & & 0.117 & & & \\
\hline & 魚沼層（シルト）Uonuma F. (silt) & -0.209 & & & & -0.215 & & & & - & & & & null & & & \\
\hline & $\begin{array}{l}\text { 灰爪層（砂質シルト岩） } \\
\text { H. }\end{array}$ & - & & & & - & & & & - & & & & 0.257 & & & \\
\hline & 西山階 (砂岩) Nishiyama S. (sandstone) & null & & & & null & & & & -0.095 & & & & null & & & \\
\hline & $\begin{array}{l}\text { 西山階（砂岩優势タービダイト層） } \\
\text { Nishiyama S. (sandrich turbidite) }\end{array}$ & 0.056 & & & & null & & & & 0.165 & & & & - & & & \\
\hline & $\begin{array}{l}\text { 西山階（砂質シルト岩） } \\
\text { Nishiyama S. (sandy siltstone) }\end{array}$ & 0.030 & & 0.8 & (3) & -0.050 & 8.3 & 3.9 & (1) & null & 0.8 & -0.2 & (7) & - & 0.8 & 0.6 & (3) \\
\hline & $\begin{array}{l}\text { 西山階（泥岩優劸タービダイト層） } \\
\text { Nishiyama S. (mudrich turbidite) }\end{array}$ & 0.188 & & & & 0.338 & & & & null & & & & 0.065 & & & \\
\hline & $\begin{array}{l}\text { 西山階（塊状泥岩） } \\
\text { Nishiyama S. (massive mudstone) }\end{array}$ & -0.068 & & & & 0.040 & & & & null & & & & 0.336 & & & \\
\hline & 椎谷階（砂岩）Siiya S. (sandstone) & - & & & & - & & & & 0.166 & & & & null & & & \\
\hline & $\begin{array}{l}\text { 椎谷階（砂岩優勢タービダイト層） } \\
\text { Siiya S. (sandrich turbidite) }\end{array}$ & - & & & & - & & & & - & & & & null & & & \\
\hline & $\begin{array}{l}\text { 椎谷階（塊状泥岩） } \\
\text { Siiya S. (massive mudstone) }\end{array}$ & -0.040 & & & & -0.082 & & & & 0.107 & & & & - & & & \\
\hline 总 & $\begin{array}{l}\text { 水平盤Horizontal dip } \\
\text { 柾目盤Dallighting dip }\end{array}$ & $\begin{array}{l}0.200 \\
0.105\end{array}$ & & & & $\begin{array}{l}-0.061 \\
0.197\end{array}$ & & & & $\begin{array}{c}\text { null } \\
0.062\end{array}$ & & & & $\begin{array}{c}\text { null } \\
0.069\end{array}$ & & & \\
\hline 翡焉㤩 & 平行盤Parallel dip & null & 1.0 & -0.6 & (6) & 0.199 & 0.2 & 0.8 & (3) & 0.066 & -0.6 & 0.8 & (5) & -0.038 & 0.2 & 0.0 & (7) \\
\hline 战 & 逆目盤Hangnail dip & null & 1.0 & 0.0 & 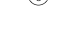 & 0.188 & 0.2 & 0.0 & 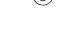 & null & 0.0 & 0.0 & & null & & & \\
\hline 吾 & 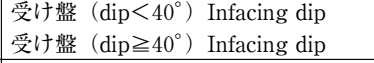 & $\begin{array}{c}0.086 \\
\text { null }\end{array}$ & & & & $\begin{array}{c}0.129 \\
\text { null }\end{array}$ & & & & $\begin{array}{c}0.158 \\
\text { null }\end{array}$ & & & & $\begin{array}{l}\text { null } \\
\text { null }\end{array}$ & & & \\
\hline & $\mathrm{N}$ & null & & & & -0.025 & & & & -0.140 & & & & null & & & \\
\hline 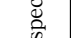 & $\mathrm{NE}$ & null & & & & -0.109 & & & & null & & & & null & & & \\
\hline $\begin{array}{c}2 \\
0 \\
0\end{array}$ & $\mathrm{E}$ & 0.170 & & & & null & & & & null & & & & null & & & \\
\hline ă & SE & 0.327 & 1.4 & 3.2 & (2) & -0.050 & 0.1 & 0.0 & (6) & null & -0.5 & 1.4 & (4) & null & 0.4 & 0.3 & (6) \\
\hline $\begin{array}{ll}\vec{n} \\
t \rightarrow 1\end{array}$ & $\mathrm{~s}$ & 0.336 & & & & 0.045 & & & & -0.059 & & & & 0.069 & & & \\
\hline 照 & SW & 0.237 & & & & null & & & & -0.175 & & & & null & & & \\
\hline 漫 & W & 0.080 & & & & null & & & & -0.201 & & & & null & & & \\
\hline 变 & NW & 0.034 & & & & -0.050 & & & & -0.226 & & & & -0.090 & & & \\
\hline 全体正 & 答率 Hit rate for the whole & $68.6 \%$ & & & & $73.5 \%$ & & & & $68.9 \%$ & & & & $67.3 \%$ & & & \\
\hline 崩壊地 & 正答率 Hit rate for landslides & $66.7 \%$ & & & & $68.5 \%$ & & & & $69.8 \%$ & & & & $74.0 \%$ & & & \\
\hline
\end{tabular}




\subsection{2 地質}

地質（岩相）の違いと崩れやすさの関倸については, 表- 2 で，7月豪雨と中越地震での違いが顕著に見える。 小崩壊・大崩壊の違いよりも, 発生機構による違いが顕 著である。中越地震では, 小崩壊・大崩壊とも, 魚沼層, 特に砂優勢の地層が崩れにくい傾向が顕著であり, 西山 階の泥岩優勢タービダイト層が崩れやすかった。7 月豪 雨の崩壊は, 規模的には小崩壊に相当するが, 栃尾地域 で係数が相対的に大きく崩れやすかったと推測されるの は, 西山階の砂岩優勢タービダイト層・椎谷階の砂岩・ 砂優勢の魚沼層であり, 出雲崎地域では西山階の塊状泥 岩・灰爪層の砂質シルト岩である。つまり 7 月豪雨では, 中越地震のケースと異なり, 魚沼層が崩れにくかったと いう傾向はなく，西山階の泥岩優勢タービダイト層が崩 れやすかったという傾向もなかった。

\subsection{3 地質構造}

地質構造は, 発生機構より崩壊規模と関連が深いよう である。小規模な崩壊（山古志地域の小崩壊，7月豪雨 による崩壊) では, ステップワイズ法で寄与なしとして 除去された変数が多く, 母岩の地質構造が表層崩壊に与 える影響が小さかった事を示唆している。小規模な崩壞 については, 山古志地域では水平盤, 栃尾地域ではdip の小さい受け盤が比較的崩れやすかった。ただし，水平 盤の分布はごく限られている。

大崩壊では, すべての流机盤（柾目盤・平行盤・逆目 盤) で係数が大きく, 中越地震の際, 流れ盤で大崩壊が 起きやすかったことを示している。佐々木ほか（2006） は, 山古志周辺の東山丘陵で行った研究から,「流れ盤, 逆目盤で規模の大きいものが発生し, 崩壊規模は地質構 造に影響を受けている」と述べているが, 本研究の結果 も調和的である。ただし， dip40度以下の受け盤でも， 比較的大崩壊が起きやすかったことが, 表 -2 から明ら かになった。水平盤では大崩壊が起きにくく, dip40度 以上の受け盤は特に傾向がなかった。

全体を通しての共通点は，「極めて不安定」とされる 柾目盤（鈴木，2000）では, 小崩壊も大崩壊も，それな りに起きやすかったことである。

\subsection{4 斜面方位}

斜面方位は, 発生機構よりも地域や崩壊規模と関連が 強いようである。

山古志地域 (中越地震) の場合, 南, 南東, 少し下がっ て南西向き斜面で小崩壊が起きやすかった傾向が，表 2 から見て取れる。他に, 山古志地域と同じ東山丘陵に位 置する栃尾地域では, 負の係数ばかり出ているが, 西お よび北西斜面で崩壊が起きにくかった傾向が見て取れ， 逆が真なら，東および南東斜面では相対的に起きやす かったことになる。従って, 東山丘陵では, 少なくとも 小規模な崩壊は, 東〜南東〜南斜面で起きやすかったと 言える。

中越地震による大崩壊のケースと, 出雲崎地域では,
ステップワイズ法で寄与なしとして除去された変数も多 く, また係数の絶対值も小さく, 斜面方位に関して確実 な傾向はないようである。

\section{4. 結論と議論}

表- 2 から, 発生機構の異なる災害を想定する場合, 小規模な斜面崩壊に共通して寄与が大きいパラメー夕は, 傾斜であることが分かる。傾斜が重要であることは従来 からずっと指摘されてきたが, あらためてその重要性が 確認された。

豪雨による斜面崩壊では, 傾斜以上に日雨量の寄与が 大きい。実は, 出雲崎地域は, 1961年の豪雨によっても 大量の崖崩れが発生している地域であり（斉藤，2007）, 崩壊密集域は日雨量が扮扮むね 200 ミ超えた地域と 重なっていることから, 雨量も極めて重要なパラメー夕 である。

地質（岩相）は，栃尾地域を除いては，傾斜や日雨量 に次ぐ要因となっている。災害の種類（豪雨・地震）に よって, 地層毎の崩れやすさには差があった。堆積岩類 に関して，野崎（1994，1995）は，魚沼・西山・灰爪層 など鮮新世以降の新しいグループと, 椎谷・寺泊層など 古いグループでは, 新しい地層の方が強度が大きいと述 べている。その中でも, 最も強度が大きいものは西山層・ 灰爪層であると述べている。一方, 川口層（西山階）は, 砂岩部分の強度が小さく, 細粒部と粗粒部の一軸圧縮強 度の差が大きいが, 荒谷層（椎谷階）では, 細粒部と粗 粒部の強度差は小さいという報告がある（野崎保博士私 信)。中越地震のケースでは, 西山階の地層の係数が高 く, 椎谷層や, 魚沼層の係数は小さく, 全体として強度 の大きい地層, 特に, 川口層の砂岩泥岩互層（表-2で は西山階のタービダイト層にあたる) のように, 細粒部 と粗粒部の強度差が大きい互層ほど崩れやすい傾向が あった。釜井 (1989) は, 同じような第三紀堆積岩類 (上 総層群) が分布する地域を襲った 1987 年の千葉県東方沖 地震について，節理や層理などの工学的分離面が関与し た例がほとんどであったと述べて抒り，中越地震の小崩 壊のケースを想起させる。大崩壊ではその傾向は薄く, 豪雨に関してはそのような傾向が見られない。このよう な傾向の差には, 地層全体の強度のみならず, 水の影響 など様々な要因が考えられ，今後の研究が待たれる。

地質構造は, 小崩壊には寄与が小さい。しかし, 規模 の大きい斜面崩壊（中越地震の大崩壊のケース）では, 無視できない素因となっている。大崩壊は, 数的には少 ないものであるが，人的被害を与える可能性がより高い。 また，流れ盤のみならず， dipが40度未満の受け盤でも， ケースによっては崩壊が起きやすかったことが明らかに なった。なお，中越地震の崩壊すべてに関しては，ケス 夕の受け盤側に多いという報告が数多く出されており, 確かに, 崩壊個数ではその通りであるが, 表- 2 からは, 傾斜・曲率・地質・斜面方位等, 他の条件が同じなら, 
$\operatorname{dip}$ が40度未満の受け盤では多少起きやすかったものの, 全体としては，流れ盤の方が不安定だったことになる。

曲率も無視できないパラメータであるが，傾斜や雨量 ほど寄与は大きくない。地震では, 曲率の絶対值が大き いほど崩れやすいという傾向が出ているが，地震の場合 凸型斜面で崩壊が起きやすいことは，従来から指摘され ていた（安江ほか，1981; 郎・中村，1997）。これは地 震波の増幅効果によるものとされている。凹型斜面も崩 れやすかった理由は, おそらく別の理由であろうが, 解 明が待たれる。なお, 図 -6 から, 地震・豪雨双方の危 険斜面を予測するためには，曲率は絶対值で考えた方が 取りこぼしがないと予想される。

斜面方位に関しては，崩壊への関与に不明な点が多い が, 中越地震の小崩壊のケースと, 栃尾地域の 7 月豪雨 のケースを総合すると, 東山丘陵では東〜南東〜南向き 斜面に何らかの崩れやすい要因がある, と言えるかもし れない。出雲崎地域では, 崩壊への斜面方位の寄与はご く小さかった。原因が分かっていない上地域によって傾 向が異なるため, 事前に「どの方位の斜面が崩れやすい のか」知ることは難しく, 傾斜方位データの利用が斜面 崩壊の対策に有効かどうかは分からない。しかし，特に 小規模な崩壊については, 崩壊地の斜面方位分布に偏り が出るということを留めておく必要はある。

以上のように, 本研究では, 従来から傾向が指摘され ていた現象を含め, 豪雨と地震による斜面崩壊の地形・ 地質条件の傾向を，中縮尺レベルのデータを用いて，定 量的に明確に示した。各パラメータの寄与の順位を示し, 豪雨と地震による崩壊の発生条件の差を明らかにした。 今後の研究の展望であるが, 斜面災害ハザードマップの ために, 崩壊危険箇所を予測するには, かつて道上 (1990) が論じたように, 各パラメータの面的な精度を上げるこ とが最も重要である。本論で行ったような中縮尺の解析 の先には, 大縮尺レベルのデー夕を使った解析もあるべ きである。

まず，崩壊地の位置デー夕について，多時期の斜面崩 壊を追跡し, 大縮尺の基眓を用いた崩壊分布図を作成し, 地形・地質条件の傾向を精査することは, 今後の研究を 発展させるであろう（例えば斉藤，2007）。ただし，大 縮尺の崩壊地データと比較するためには, 他のパラメー 夕も，それなりの位置精度を持っている必要がある。近 年, 航空レーザ測量の進歩により, 地形データについて はようやく，その土台ができつつある。

各変数の中で, 豪雨・地震どちらのタイプの斜面崩壊 でも重要なのは, 傾斜である。何より, 傾斜分級図の面 的な精度を上げることが，今後の斜面崩壊の対策に役立 つと考えられるが，それには，航空レーザ測量等の詳細 なDEMが，今後助けになるだろう。DEMからは，定量 的な地形デー夕, 特に傾斜や曲率などが取得できる。地 質のデータに関しては，一朝一夕に大縮尺のデータが入 手できるというような性質のものではない。ただし，従
来の地質図でも, 解説書に記載された内容から岩相分類 をある程度把握することは可能であろう。地質構造は, 小規模な崩壊に関しては, 今回扱った地域では，崩壊・ 非崩壊の判別に余り寄与しておらず，危険斜面のふるい 分けに際してさほど考慮する必要がなかったが，他の地 形・地質条件では重要になるかもしれない。ただし，地 震時の大規模な崩壊には重要であることが明らかになっ た。斜面方位についても，いかなる地域でも共通して斜 面防災に役立てられるというようなデータではないが， 地震時の小崩壊に関しては, 強い影響がありそうである。 豪雨による斜面崩壊の発生に関して, 雨量のデータが 傾斜に劣らず重要であることは, 表一 2 から推測される 通りである。河島ほか（2005）は，アメダスデータだけ を用いて集中豪雨の降雨域を正確に把握するには限界が あり，斜面災害の発生と雨量との対応を調べるには様々 な機関の観測データの一元化に向けた取り組みが強く望 まれると述べている。国土交通省と気象庁の観測データ については，平成15年から運用が開始された国土交通省 防災気情報提供センターのリアルタイム降水量・リアル タイムレーダーで統合されている。ただし, 地方自治体 の観測点は入っていない。また，一部の自治体等では 250 $\mathrm{m}$ 解像度の降雨レーダーが整備されつつある（東京都下 水道局の「東京アメッシュ」; 大阪市都市環境局降雨情 報「オークレーダ」; 神戸市降雨情報システム「レイン マップこうべ250」等）が，今の所大都市のみであり， 地方や山間地に於いてはまだ完全とは言えない現状があ る。今後の整備が待たれる。

\section{5. 謝辞}

新潟大学災害復興科学センターの河島克久准教授には, 2004年豪雨時の気象のデータをいただいた。産業総合研 究所地質情報研究部門の小松原环主任研究員には, 数值 地質図データをいただいた他，地質罒の接合についてご 意見をいただいた。(株アーキジオ新潟の野崎保博士には, 第三紀堆積岩類の岩石物性について私信を頂いた。防災 科学技術研究所の若松加寿江博士 ・日本技術開発株式会 社の末冨岩雄博士には, 中越地震の推定地震加速度につ いてデータのご教示をいただいた。駒澤大学の田中靖講 師には，曲率についてご教示いただいた。以上の方々に， 深く感謝する。

\section{引用文献}

Carrara, A., Cardinali, M., Detti, R., Guzzetti, F., Pasqui, V., Reichenbach, P.(1991): GIS techniques and statistical models in evaluating landslide hazard. Earth Surface Process and landforms, 16, pp. $427-445$.

Chigira, M., Yagi, H.(2006) : Geological and geomorphological characteristics of landslides triggered by the 2004 Mid Niigata prefecture earthquake in Japan.Eingineering Geology, 82, pp. $202-221$.

Guzzetti, A., Carrara, A., Cardinali, M., Reichenbach, P.(1999) : Landslide hazard evaluation : a review of current techniques 
and their application in a multi-scale study, Central Italy.Geomorphology, 31, pp. 181-216.

本多泰章（2006）：GISを用いた斜面崩壊のハザード分布一新潟県 中越地震（2004年）と関東大地震（1923年）を例として-。 全国測量技術大会2006学生フォーラム発表論文集，8，pp. 510 .

Iwahashi, J., Watanabe, S., Furuya, T.(2001) : Landform analysis of slope movements using DEM in Higashikubiki area, Japan. Computers \& Geosciences, 27, pp. 851-865.

岩橋純子・佐藤浩・山岸宏光 (2006)：新潟県中越地震による小崩 壊の分布特性 - 平成16年新潟県中越地震 $1: 25,000$ 災害状況 眓のデータを中心に一． 国土地理院時報，110，pp. 81-89.

釜井俊孝（1989）：1987年千葉県東方沖地震による上総丘陵の斜面 崩壊－崩壊の分類と安定の検討－．地すべり，Vol. 26, No.2, pp. $1-8$.

川邊洋・権田豊・丸井英明・渡部直喜 (2005)：新潟県中越地震に よる土砂災害. 新潟県連続災害の検証と復興への視点 2004.7.13水害と中越地震の総合的検証 - . 新潟大学・中越地 震新潟大学調查団, pp. $130-139$.

河島克久・和泉薰・伊豫部勉 (2005)：平成16年 7 月新潟・福島豪 雨時の気象状況と詳細な降雨分布。平成16年 7 月新潟・福島, 福井豪雨災害に関する調査研究 (平成16年度科学研究費補助 金（特別研究促進費 $(1)$ ) 研究成果報告書, pp. 23-39.

小林䉷雄・立石雅昭・植村武（1993）：出雲崎地域の地質。地域地 質研究報告 ( 5 万分の 1 地質図幅), 地質調查所, $91 \mathrm{p}$.

小林㒈雄・立石雅昭・小松原环（2001）：三条地域の地質．地域地 質研究報告 ( 5 万分の 1 地質図幅), 産総研地質調查総合セン 夕ー, $98 \mathrm{p}$.

小林嚴雄・立石雅昭 - 吉村尚久 ·上田哲郎 - 加藤碵一 (1995)：柏 崎地域の地質. 地域地質研究報告 ( 5 万分の 1 地質図幅), 地 質調査所，132p. 102p.

郎寬華・中村浩之（1997）：地震による崩壊の特徵とそのモデル斜 面における理論的解析一中国永登地震を例として一。地す心 り, Vol. 34, No. 3, pp. 25-33.

丸井英明・渡部直喜・川邊洋・権田豊（2005）：中越地震による斜 面災害と融雪の影響について。新潟県連続災害の検証と復興 への視点 -2004.7 .13 水害と中越地震の総合的検証 - . 新潟 大学・中越地震新潟大学調查団, pp. $148-155$.

道上正規（1990）：豪雨による土砂崩壊の予測に関する研究．文部 省科学研究費重点領域研究「自然災害の予測と防災力」研究 成果, $165 \mathrm{p}$.

西山賢一・千木良雅弘（2002）：1982年長崎豪雨災害で発生した斜 面崩壊の地質的特長. 京都大学防災研究所年報, $45-\mathrm{B}, \mathrm{pp}$ $47-60$.

野崎保 (1994)：新潟県下における地すべり母岩の力学特性（前編） 一室内試験に扔ける岩石力学特性一。地すべり, Vol. 31, No. 2, pp. $17-23$.

野崎保 (1995)：新潟県下における地すべり母岩の力学特性（前編） 一原位置試験による岩石力学特性一。地すべり, Vol. 32, No. 2 , pp. $17-25$.

沖村孝（1996）：六甲山地における山腹斜面の崩壊. 兵庫県南部地 震と地形琰害, 日本地形学連合編, pp. 110-126.

Pike, R. J., Sobieszczyk, S. (2007) : Soil slip/debris flow localized by site attributes and wind-driven rain in the San Francisco Bay region storm of January 1982. Geomorphology (in press) 斉藤正弥（2007）：出雲崎地域における2004.7.13新潟豪雨による 崩壊 - 地形・地質要因の検討 - . 2006年度 新潟大学大学院 自然科学研究科研究報告書. $119 \mathrm{p}$.
佐々木靖人・塩見哲也・阿南修司（2006）：地形・地質．平成16年 （2004年）新潟県中越地震土木施設災害調査報告，土木研究所 報告， 203，pp. $1-24$

関口辰夫・佐藤浩（2006）：新潟県中越地震における斜面崩壊の特 徵と分布. 日本地すべり学会誌，Vol. 43，No. 3，pp. 14-26.

柴原俊昭 (2001)：山地の斜面崩壊に与える森林の影響について. 理工研NEWS, 30, 日本大学理工学部理工学研究所.

末冨岩雄・福島康宏・石田栄介・磯山龍二・澤田純男（2006）： 2004年新潟県中越地震の地震動分布推定における補間計算条 件の影響, 第12回日本地震工学シンポジウム論文集, pp. 1494 $-1497$.

末冨岩雄・石田栄介・福島康宏・磯山龍二 ・澤田純男 (2007)：地 形分類とボーリングデータの統合処理による地盤増幅度評価 と2004年新潟県中越地震に扮ける地震動分布の推定. 地震工 学会論文集, $7(3)$, pp. 1-12.

鈴木義宜・丹羽俊二 ・田口益雄 - 関崎賢一 - 長谷川学 - 飯田誠 · 門脇利広（2005）：新潟県中越地震の災害状況図作成について。 国土地理院時報, 107, pp. 53-63.

鈴木隆介（1997）：建設技術者のための地形図読図入門（第 1 巻 読図の基礎)．古今書院，200p .

鈴木隆介（2000）：建設技術者のための地形図読図入門（第 3 巻段 丘・丘陵・山地). 古今書院, $942 \mathrm{p}$.

武田裕幸・今村遼平 (1996)：応用地学ノート。共立出版, 447p.

竹内圭史・柳沢幸夫 - 宮崎純一 - 尾崎正紀 (2004)：中越魚沼地域 の 5 万分の 1 数值地質図 (Ver.1). 地質調査総合センター研 究資料集, no. 412, 産業技術研究所地質調查総合センター.

牛山素行（2004）：2004年 7 月12～13日の新潟県における豪雨災害 の特徵. 自然災害科学, $23(2), p p .293-302$.

八木浩司・山崎孝成・渥美賢拓（2007）：2004年中越地震にともな う地すべり・崩壊発生場の地形・地質的特徵のGIS解析と土 質特性の検討. 日本地すべり学会誌，Vol. 43，No. 5，pp. 44 -56 .

Yamagishi, H., Ayalew, L., Watanabe, N., Marui, H. and Kawabe, H.(2005) : Landslides induced by the July 13, 2004 heavy rainfall in Mid Niigata Region. 平成16年 7 月新潟・福島，福 井豪雨災害に関する調查研究 (平成16年度科学研究費補助金 （特別研究促進費 (1)) 研究成果報告書, pp. 84-93.

山岸宏光・丸井英明・渡辺直樹 - 川邊洋（2005）：2004年新潟県中 越地域 2 大同時多発斜面災害の特徵と比較. 新潟県連続災害 の検証と復興への視点 -2004.7 .13 水害と中越地震の総合的 検証 - . 新潟大学・中越地震新潟大学調查団, pp. 140-147.

Yamagishi, H., Takayama, T., and Iwahashi, J.(2006) : Landslides and landscape change induced by heavy rainfall and intensive earthquake in Mid-Niigata, Japan : GIS analyses and interpretation of aerial photographs. In Marui, H. et al (ed). Disaster Mitigation of Debris Flows Slope Failures and Landslides vol2. Proceeding of the INTERPREVENT International Symposium September 25-29, 2006in Niigata, Japan, pp. $605-615$.

安江朝光・岩崎敏男 - 川島一彦・仲野公章 (1981)：斜面の地震応 答特性の解析. 土木技術資料， 23 ( 4)，pp. 21-26.

横山俊治・菊山浩喜（1997）：1995年兵庫県南部地震時に発生した 六甲花崗岩地域の斜面崩壊の運動様式と機構. 地すべり, Vol. 34, No. 3, pp. 17-24.

Zevenbergen, L.W., Thorne, C.R. (1987) : Quantitative analysis of land surface topography. Earth Surface Process and Landforms, 12 , pp. $47-56$.

（原稿受付2007年 4 月11日，原稿受理2007年10月 1 日） 